\title{
Proximate and Elemental Composition of Important Fish Species in Makkah Central Fish Market, Saudi Arabia
}

\author{
Shady M. El Shehawy ${ }^{1,2^{*}}$, Ali A. Gab-Alla1,3, Hamed M. A. Mutwally ${ }^{1}$ \\ ${ }^{1}$ Biology Department, Faculty of Applied Science, Umm Al-Qura University, Makkah, Saudi Arabia \\ ${ }^{2}$ Food Industries Department, Faculty of Agriculture, Mansoura University, Mansoura, Egypt \\ ${ }^{3}$ Marine Biology Department, Faculty of Science, Suez Canal University, Ismailia, Egypt \\ Email:yshmtu10@mans.edu.eg
}

Received 20 March 2016; accepted 21 May 2016; published 24 May 2016

Copyright (C) 2016 by authors and Scientific Research Publishing Inc.

This work is licensed under the Creative Commons Attribution International License (CC BY). http://creativecommons.org/licenses/by/4.0/

(c) ()

\begin{abstract}
In spite of the established nutritive value of seafood, fishes have a special ability to store some toxic substances such as heavy metals because of its own respiration system. The goal of current study was to explore the proximate chemical composition, minerals content and levels of heavy metals in edible portions of some important commercial fish species available at Makkah Central Fish Market, Saudi Arabia. The obtained results showed that Indian oil sardine fish had the highest value of crude oil (dry weight) recorded $\mathbf{3 8 . 0 0 \%}$, while, rusty parrot fish sample had the least of $1.17 \%$. In contrast, rusty parrot fish had the highest value of crude protein represented $90.75 \%$ (dry weight), meanwhile, Indian oil sardine had the least of $54.19 \%$. Consuming about $250 \mathrm{~g}$ of Indian oil sardine will cover $100 \%$ of Fe RDA (Recommended Dietary Allowances), eating $500 \mathrm{~g}$ of the same fish will cover about $30 \%$ of Ca RDA. While, $500 \mathrm{~g}$ of gilt head bream which has the highest content of $\mathrm{K}$, $\mathrm{Na}$ and $\mathrm{Mg}$ will cover about $11.7 \%, 1.5 \%$ and $4.1 \%$ of these minerals $\mathrm{RDA}$, respectively. As physical hazards, fourteen samples from the thirty three studied samples exceeded the permissible limit of $\mathrm{Pb}$ and $\mathrm{Cd}$ representing about $42 \%$. Therefore, it is strongly recommended not to eat head, gills or viscera of all fishes.
\end{abstract}

\section{Keywords}

Fish, Proximate Chemical Composition, Minerals, Heavy Metals, Metal Pollution Index

\section{Introduction}

Although seafood is considered as a main source of high biological value protein, polyunsaturated oil and minerals such as calcium, potassium, fish form an important target for bio-magnifications of heavy metals as they 
are at the top of food pyramid and act as a possible transfer media to human beings [1].

Levels of nine nutrient minerals and proximate components of fresh edible portions of some commercially important finfish and shellfish in Arabian Gulf, Saudi Arabia, were examined [2]. This study reported that all the fish investigated were fairly high in protein $(18 \%-22 \%)$, while the lipid content was less than $3 \%$. Moisture and ash contents ranged from $74.90 \%-79.50 \%$ and $1.01 \%-1.50 \%$, respectively. The level of minerals varied from one fish species to another. In finfish, the most abundant mineral was potassium followed by phosphorus with lower levels of sodium, magnesium and calcium. The amount of calcium ranged from $57.3 \mathrm{ppm}$ to $959 \mathrm{ppm}$. While, magnesium varied within a relatively narrow range in finfish (250 - $350 \mathrm{ppm}$ ).

Forty of Tilapia niloticus fish and water samples were collected by El-Ghasham et al. (2008) [3] from four different main farms (10 fishes each) at Burayda, Qassim region, Saudi Arabia. Levels of lead (Pb) and cadmium (Cd) were determined in water and fish tissues using atomic absorption spectrophotometer and their levels are compared to figures recommended by the World Health Organization (WHO). The mean levels of $\mathrm{Pb}(0.4$ $\mathrm{ppm})$ and $\mathrm{Cd}(0.1 \mathrm{ppm})$ in fish tissues were apparently lower than the values permitted by WHO (1.5 ppm for Pb and $0.2 \mathrm{ppm}$ for $\mathrm{Cd})$.

On the other hand, three highly consumed fishes in Saudi market were evaluated for their chemical composition. The fish species were locally known as Kanad, Hammour and Hammam in Saudi market. The moisture, protein, total lipids and ash of the muscle tissue and head were between $71.20 \%-78.23 \%, 16.19 \%-20.20 \%$, $0.24 \%-4.10 \%$ and $1.10 \%-8.00 \%$, respectively [4].

Moreover, the concentration of some heavy metals ( $\mathrm{Fe}, \mathrm{Mn}, \mathrm{Cu}, \mathrm{Zn}, \mathrm{Pb}, \mathrm{Cd}$ and $\mathrm{Hg}$ ) in certain common fish species (blackspotemperors, grouper and sardines), meat and meat products collected from four major industrial and urban cities (Tabouk, Riyadh, Damamm and Jazan) in Kingdom of Saudi Arabia were assessed using atomic absorption spectrophotometer. The obtained results declared that concentrations of major studied metals were exceeding than the recommended maximum acceptable levels proposed by the Joint FAO/WHO and EC Committees [5].

Saudi Arabia sets a permissible limit of lead and cadmium in fish as 2.0 and $0.5 \mathrm{ppm}$, respectively [6], whereas, European Commission (1997) [7] proposed limits for Pb and Cd in fish being $0.5 \mathrm{ppm}$ for each metal. The WHO (1993) [8] stated that the level of Cd in fish was $0.2 \mathrm{ppm}$.

The objective of this study was to determine the proximate chemical composition, minerals content such as calcium $(\mathrm{Ca})$, potassium $(\mathrm{K})$, sodium $(\mathrm{Na})$, iron $(\mathrm{Fe})$ and magnesium $(\mathrm{Mg})$ and levels of heavy metals i.e., lead $(\mathrm{Pb})$, cadmium $(\mathrm{Cd})$, copper $(\mathrm{Cu})$ and manganese $(\mathrm{Mn})$ in the edible portion of some important commercial fish species available in Makkah Central Fish Market, Saudi Arabia. Consequently, nutritive data base of some Saudi fish will be available for dietitians and nutrition program designers.

\section{Materials and Methods}

\subsection{Materials}

Three replicates of eleven fresh fish species were randomly collected from the Central Fish Market, ElKaakia, Makkah, Saudi Arabia during spring 2015. They were classified and named as follows: grey mullet Liza ramada, sabaki tilapia Oreochromis spilurus, indian oil sardine Sardinella longiceps, golden thread fin bream Nemipterus japonicus, gilt head bream Sparus aurata, asian seabass Lates calcarifer, job fish Apharus rutilanus, spangled emperor Lethrinus nebuloses, dusky grouper Epinephelus marginatus, rusty parrot fish Scarus ferrugineus and half spotted grouper Cephalopholis hemistiktos. These species are commonly consumed by the locals in Saudi Arabia. Fish samples were mixed with soft ice, put in ice box and transported to biology department Lab, Faculty of Applied Science, Umm Al-Qura University, Makkah, Saudi Arabia.

\subsection{Methods}

\subsubsection{Samples Preparation}

Tissues of the examined fish were dissected, using clean equipment. Moisture content was determined, then put in petri dishes and transferred into an oven set to $70^{\circ} \mathrm{C}$ to dry. Drying continued until all wet tissues reached to a constant weight. Finally, all dried samples were grinded and stored at $-18^{\circ} \mathrm{C}$ for chemical analysis.

\subsubsection{Chemical Analysis}

Percentage of moisture and ash content were determined according to the method described by AOAC (2005) 
[9].

Crude oil content was extracted by soxelt apparatus using petroleum ether $\left(40^{\circ} \mathrm{C}-60^{\circ} \mathrm{C}\right)$ as a solvent according to the method described in AOAC (2005) [9].

Total nitrogen content (TN) was determined in fish muscle sample using the micro-Kjeldahl method as mentioned by AOAC (2005) [9].

Heavy metals ( $\mathrm{Pb}, \mathrm{Mn}, \mathrm{Cu}$ and $\mathrm{Cd}$ ) and minerals (Ca, K, Na, Fe and $\mathrm{Mg}$ ) were determined out in Central Laboratory Unit, High Institute of Public Health, Alexandria University, Egypt. Minerals were analyzed using atomic absorption spectrophotometer (Perkin-Elmer Model 2380) according to the method of AACC (1983) [10].

As for heavy metals, dry tissue samples (triplicate each $0.2 \mathrm{~g}$ ) were put into digestion flasks followed by addition of $5 \mathrm{ml}$ nitric acid (Merck), $2 \mathrm{ml}$ perchloric acid and heated at $90^{\circ} \mathrm{C}$ until all the materials were dissolved. After digestion, the digested samples were diluted with deionized water, filtered and completed, using deionized water to $10 \mathrm{ml}$. The resulting solutions were analyzed, using flame atomic absorption spectrophotometer (Perkin Elmer, Model 2380). Results were expressed in ppm dry weight [11].

The overall metal contents of fish samples investigated in this study were compared, using Metal Pollution Index (MPI) calculated by multiplication of studied heavy metal concentrations (ppm), then $4^{\text {th }}$ root of the result using the formula reported by Usero et al. (1997) [12].

$$
\mathrm{MPI}=(\mathrm{Pb} \times \mathrm{Mn} \times \mathrm{Cu} \times \mathrm{Cd})^{I / 4}
$$

\subsubsection{Statistical Analysis}

Statistical analysis including mean, standard error and analysis of variance (one way ANOVA) test were done using SPSS (2008) [13] version 17 program for windows.

\section{Results and Discussion}

The major constituents in the edible portion of fish are water, protein, lipid (fat or oil) and ash (minerals). Analysis of these basic constituents is often referred to proximate analysis. Results in Table 1 showed approximate chemical composition of studied fish. Moisture content ranged from $58.27 \%$ in Indian oil sardine to $79.41 \%$ in rusty parrot fish. Ash \% (dry weight) ranged between $1.20 \%$ and $5.78 \%$ in grey mullet and half spotted grouper, respectively. As for crude oil, Indian oil sardine sample had the highest value of crude oil (dry weight) recording $38.00 \%$, while rusty parrot fish sample had the least value of $1.17 \%$. Finally, rusty parrot fish sample had the highest value of crude protein represented $90.75 \%$, meanwhile, Indian oil sardine had the least of $54.19 \%$.

Statistical analysis showed significant differences between fish samples in their content of moisture, ash, crude oil and crude protein at $P<0.05$ with $F$ value of 52.92, 12.90, 82.35 and 76.94, respectively.

From results, it could be clearly seen reverse relationship between moisture and crude oil content, as it was well known for all fish processing technologists. Moreover, the sum of moisture (\%) and crude oil (\% - wet weight) ranged from $74.27 \%$ in gilt head bream to $79.78 \%$ in Sabaki Tilapia. Also, it could be noticed that three fish samples only had ash content below $2 \%$ named grey mullet, Sabaki Tilapia and golden thread fin bream, and so, they were poor in minerals. In the same manner, only four fish samples had crude oil content below 3\% (dry weight) named job fish, spangled emperor, rusty parrot fish and half spotted grouper and classified as lean fish. For example, Malaysian authors [14] analyzed the biochemical compositions of three fish. The proximate analysis revealed that the protein content of Channa lucius, Channa micropeltes and Channa striatus was 19.9\%, $22.1 \%, 23.0 \%$ (dry weight), respectively. The total lipid content was generally high, ranging from $5.7 \%$ to $11.9 \%$ and crude ash ranged from $1.0 \%$ to $1.8 \%$.

The results agreed with those reported by Tawfik (2009) [4] and Di Lena, et al. (2016) [15], who determined proximate composition for red mullet (Mullus barbatus) caught in the Central Tyrrhenian and Central Adriatic seas. Results showed that, in fish from both sites, protein $(18.1 \%-18.8 \%)$ and ash $(1.27 \%-1.42 \%)$ contents were almost stable. Total lipid contents were highly variable, with very low levels in spring $(0.96 \%-1.48 \%)$ and high levels in autumn (7.28\% - 8.72\%). However, it must put in consideration that, the biochemical composition of fish is influenced by a number of factors such as biological variations, environmental conditions and seasonal changes.

As for minerals, they play an important role in human nutrition as iron is an essential element for most life on Earth, including human. It is needed for a number of highly complex processes that continuously take place on a 
Table 1. Proximate chemical composition of studied fish flesh samples.

\begin{tabular}{|c|c|c|c|c|}
\hline Components & Moisture \% & $\begin{array}{c}\text { Ash \% } \\
\text { (Dry Weight) }\end{array}$ & $\begin{array}{l}\text { Crude Oil \% } \\
\text { (Dry Weight) }\end{array}$ & $\begin{array}{l}\text { Crude Protein \% } \\
\text { (Dry Weight) }\end{array}$ \\
\hline $\begin{array}{l}\text { Grey mullet } \\
\text { Liza ramada }\end{array}$ & $69.72 \pm 0.02^{\mathrm{b}}$ & $1.20 \pm 0.07^{\mathrm{a}}$ & $29.13 \pm 0.84^{\mathrm{d}}$ & $67.25 \pm 0.89^{b}$ \\
\hline $\begin{array}{l}\text { Sabaki Tilapia } \\
\text { Oreochromis spilurus }\end{array}$ & $75.96 \pm 0.42^{\mathrm{cd}}$ & $1.25 \pm 0.07^{\mathrm{a}}$ & $15.87 \pm 1.35^{c}$ & $80.25 \pm 1.01^{\mathrm{c}}$ \\
\hline $\begin{array}{l}\text { Indian oil sardine } \\
\text { Sardinella longiceps }\end{array}$ & $58.27 \pm 1.75^{\mathrm{a}}$ & $5.31 \pm 0.19^{b}$ & $38.00 \pm 3.67^{\mathrm{e}}$ & $54.19 \pm 3.56^{\mathrm{a}}$ \\
\hline $\begin{array}{l}\text { Golden thread fin bream } \\
\text { Nemipterus japonicus }\end{array}$ & $77.24 \pm 0.50^{\text {cde }}$ & $1.56 \pm 0.17^{\mathrm{a}}$ & $9.68 \pm 0.36^{\mathrm{b}}$ & $86.11 \pm 0.39^{d}$ \\
\hline $\begin{array}{l}\text { Gilt head bream } \\
\text { Sparus aurata }\end{array}$ & $69.83 \pm 1.07^{\mathrm{b}}$ & $4.61 \pm 0.28^{b}$ & $14.71 \pm 0.26^{\mathrm{c}}$ & $79.35 \pm 0.47^{\mathrm{c}}$ \\
\hline $\begin{array}{l}\text { Asian seabass } \\
\text { Lates calcarifer }\end{array}$ & $75.65 \pm 1.03^{\mathrm{c}}$ & $5.15 \pm 0.18^{\mathrm{b}}$ & $4.46 \pm 0.61^{\mathrm{a}}$ & $89.13 \pm 0.87^{\mathrm{de}}$ \\
\hline $\begin{array}{c}\text { Job fish } \\
\text { Apharus rutilanus }\end{array}$ & $76.38 \pm 0.92^{\mathrm{cd}}$ & $5.64 \pm 0.11^{\mathrm{b}}$ & $1.99 \pm 0.35^{\mathrm{a}}$ & $90.74 \pm 0.36^{\mathrm{e}}$ \\
\hline $\begin{array}{l}\text { Spangled emperor } \\
\text { Lethrinus nebuloses }\end{array}$ & $77.74 \pm 0.79^{\text {cde }}$ & $5.76 \pm 0.21^{b}$ & $2.78 \pm 0.05^{\mathrm{a}}$ & $90.15 \pm 0.10^{\text {de }}$ \\
\hline $\begin{array}{c}\text { Dusky grouper } \\
\text { Epinephelus marginatus }\end{array}$ & $78.03 \pm 0.84^{\text {cde }}$ & $5.28 \pm 0.09^{b}$ & $4.54 \pm 1.64^{\mathrm{a}}$ & $88.88 \pm 1.88^{\mathrm{de}}$ \\
\hline $\begin{array}{l}\text { Rusty parrot fish } \\
\text { Scarus ferrugineus }\end{array}$ & $79.41 \pm 0.33^{\mathrm{e}}$ & $4.88 \pm 1.17^{\mathrm{b}}$ & $1.17 \pm 0.26^{\mathrm{a}}$ & $90.75 \pm 0.65^{\mathrm{e}}$ \\
\hline $\begin{array}{l}\text { Half spotted grouper } \\
\text { Cephalopholis hemistiktos }\end{array}$ & $78.59 \pm 0.13^{\text {de }}$ & $5.78 \pm 1.19^{b}$ & $2.55 \pm 0.73^{\mathrm{a}}$ & $89.41 \pm 0.31^{\mathrm{de}}$ \\
\hline$F$ value & 52.92 & 12.90 & 82.35 & 76.94 \\
\hline
\end{tabular}

Mean values \pm standard error $(\mathrm{n}=3)$. Means of treatments having the same letter(s) within a column are not significantly different $(P<0.05)$.

molecular level and that is indispensable to human life, e.g. the transportation of oxygen around human body [16]. Table 2 showed some minerals concentration (ppm) of studied fish samples such as $\mathrm{Ca}, \mathrm{K}, \mathrm{Na}$, Fe and $\mathrm{Mg}$. Obtained results showed iron (Fe) ranged from 10.55 to $67.18 \mathrm{ppm}$ in rusty parrot fish and Indian oil sardine, respectively. Calcium is a mineral that must be constantly eaten to build bone and maintain the blood level of calcium [17]. Tabulated data showed that Indian oil sardine had the highest content of calcium (785.18 ppm) followed by golden thread fin bream (457.59), while rusty parrot fish had the least content of $74.02 \mathrm{ppm}$. Potassium is a very significant body mineral, important to both cellular and electrical function [17]. It varied from the least value of $83.54 \mathrm{ppm}$ in half spotted grouper sample to the highest value of $110.61 \mathrm{ppm}$ in gilt head bream.

Sodium helps maintain normal blood pressure and normal function of muscles and nerves [17]. Table 2 showed that sodium content of studied fresh fish samples ranged from 34.92 to $46.58 \mathrm{ppm}$ in half spotted grouper and gilt head bream, respectively. Finally magnesium ions regulate over 300 biochemical reactions in the body through their role as enzyme co-factors [17]. Gilt head bream sample had the highest content of magnesium, represented $34.36 \mathrm{ppm}$, meanwhile half spotted grouper sample had the least content (26.37 ppm). Data illustrated in Figure 1 showed Fe and Ca content (ppm) of all studied fish flesh samples. It could be clearly noticed that Indian oil sardine sample had the highest content of Fe and Ca between all studied samples with highly significant differences at $P<0.05$. Whilst, tabulated results insured that gilt head bream sample had the highest content of $\mathrm{K}, \mathrm{Na}$ and $\mathrm{Mg}$ with moderate significant differences, at $P<0.05$ with $F$ value of 1.27, 1.12 and 1.11, respectively.

However, the results ensured that fish is considered as a main source of many minerals that are very important for human. These findings were in close link with those obtained by Mogobe et al. (2015) [19], who carried out a study to determine essential mineral content of some common fish species in the Okavango Delta, Botswana and assess their potential in enhancing mineral intake. They reported that the concentration ranges of minerals were within FAO mean concentration ranges for fish and comparable to values obtained from other previous studies. The results showed that fishes of Chanoga have a good supply of minerals and can be used for enhancing mineral intake and protecting the community from mineral deficiency diseases. Also, comparative analysis of 


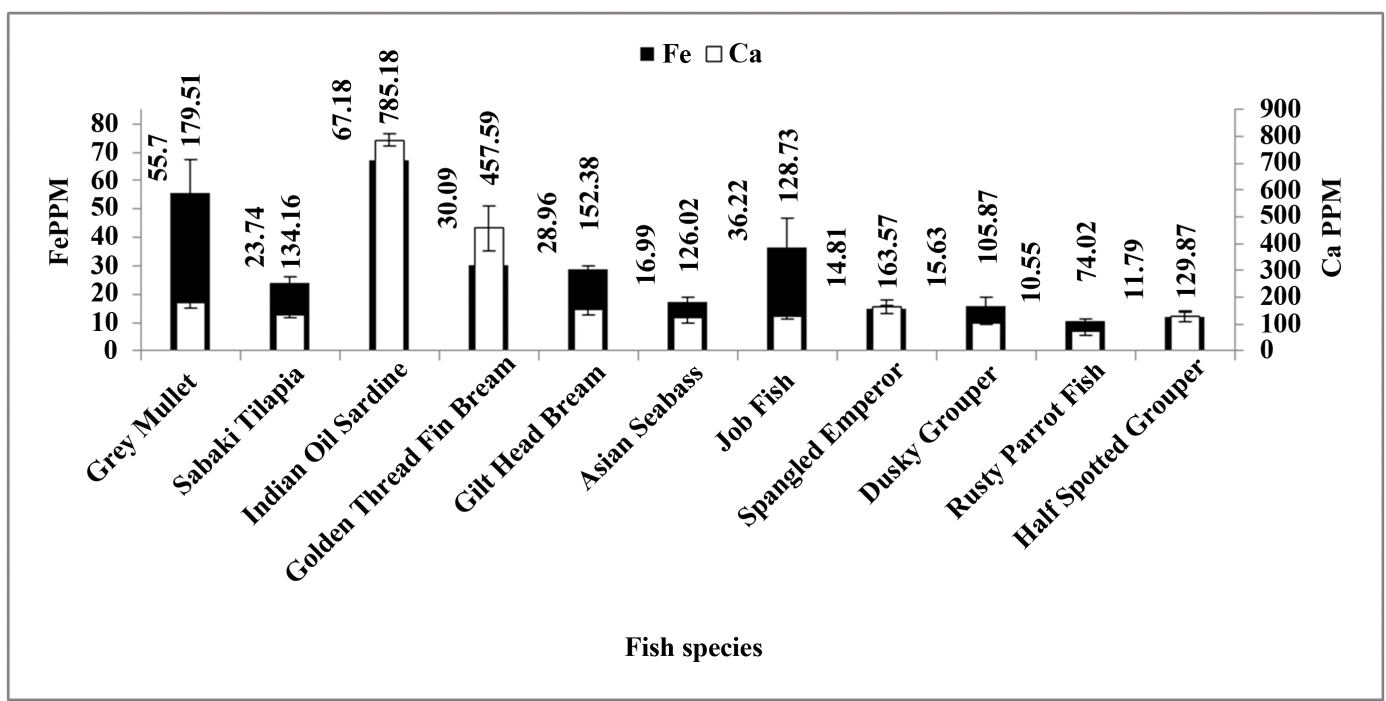

Figure 1. Fe and Ca content (ppm) of studied fish flesh samples.

Table 2. Minerals content (ppm), dry weight, of studied fish flesh samples.

\begin{tabular}{|c|c|c|c|c|c|}
\hline Fish species $\quad$ Minerals & $\mathbf{F e}$ & Ca & $\mathbf{K}$ & $\mathrm{Na}$ & Mg \\
\hline $\begin{array}{l}\text { Grey mullet } \\
\text { Liza ramada }\end{array}$ & $55.70 \pm 11.84^{\mathrm{a}}$ & $179.51 \pm 19.01^{\mathrm{c}}$ & $107.94 \pm 6.97^{\mathrm{a}}$ & $45.39 \pm 2.96^{\mathrm{ab}}$ & $33.89 \pm 2.09^{\mathrm{ab}}$ \\
\hline $\begin{array}{c}\text { Sabaki Tilapia } \\
\text { Oreochromis spilurus }\end{array}$ & $23.74 \pm 2.54^{\text {bcde }}$ & $134.16 \pm 9.00^{\mathrm{cd}}$ & $105.19 \pm 0.74^{\mathrm{ab}}$ & $45.10 \pm 0.87^{\mathrm{ab}}$ & $33.38 \pm 0.58^{\mathrm{ab}}$ \\
\hline $\begin{array}{l}\text { Indian oil sardine } \\
\text { Sardinella longiceps }\end{array}$ & $67.18 \pm 4.04^{\mathrm{a}}$ & $785.18 \pm 23.48^{a}$ & $103.60 \pm 1.58^{\mathrm{ab}}$ & $42.71 \pm 0.65^{\mathrm{ab}}$ & $32.45 \pm 0.45^{\mathrm{ab}}$ \\
\hline $\begin{array}{l}\text { Golden thread fin } \\
\text { bream } \\
\text { Nemipterus japonicus }\end{array}$ & $30.09 \pm 3.92^{\mathrm{bc}}$ & $457.59 \pm 84.71^{b}$ & $107.97 \pm 2.39^{\mathrm{a}}$ & $44.68 \pm 1.23^{\mathrm{ab}}$ & $33.84 \pm 0.89^{\mathrm{ab}}$ \\
\hline $\begin{array}{l}\text { Gilt head bream } \\
\text { Sparus aurata }\end{array}$ & $28.96 \pm 1.03^{\mathrm{bcd}}$ & $152.38 \pm 20.09^{\mathrm{cd}}$ & $110.61 \pm 1.20^{\mathrm{a}}$ & $46.58 \pm 0.14^{\mathrm{a}}$ & $34.36 \pm 0.27^{\mathrm{a}}$ \\
\hline $\begin{array}{l}\text { Asian seabass } \\
\text { Lates calcarifer }\end{array}$ & $16.99 \pm 1.72^{\text {cde }}$ & $126.02 \pm 23.93^{\mathrm{cd}}$ & $100.90 \pm 3.31^{\mathrm{ab}}$ & $42.47 \pm 1.60^{\mathrm{ab}}$ & $31.68 \pm 1.17^{\mathrm{ab}}$ \\
\hline $\begin{array}{c}\text { Job fish } \\
\text { Apharus rutilanus }\end{array}$ & $36.22 \pm 10.68^{b}$ & $128.73 \pm 9.90^{\mathrm{cd}}$ & $96.31 \pm 1.01^{\mathrm{ab}}$ & $41.35 \pm 0.60^{\mathrm{ab}}$ & $30.74 \pm 0.29^{\mathrm{ab}}$ \\
\hline $\begin{array}{l}\text { Spangled emperor } \\
\text { Lethrinus nebuloses }\end{array}$ & $14.81 \pm 1.13^{\text {cde }}$ & $163.57 \pm 24.35^{\mathrm{cd}}$ & $100.31 \pm 6.47^{\mathrm{ab}}$ & $43.38 \pm 2.25^{\mathrm{ab}}$ & $32.19 \pm 1.50^{\mathrm{ab}}$ \\
\hline $\begin{array}{c}\text { Dusky grouper } \\
\text { Epinephelus marginatus }\end{array}$ & $15.63 \pm 3.31^{\text {cde }}$ & $105.87 \pm 6.22^{\mathrm{cd}}$ & $98.55 \pm 5.49^{\mathrm{ab}}$ & $43.35 \pm 3.02^{\mathrm{ab}}$ & $32.50 \pm 1.83^{\mathrm{ab}}$ \\
\hline $\begin{array}{l}\text { Rusty parrot fish } \\
\text { Scarus ferrugineus }\end{array}$ & $10.55 \pm 0.92^{\mathrm{e}}$ & $74.02 \pm 16.62^{\mathrm{e}}$ & $90.37 \pm 17.93^{\mathrm{ab}}$ & $38.98 \pm 7.77^{\mathrm{ab}}$ & $29.10 \pm 5.65^{\mathrm{ab}}$ \\
\hline $\begin{array}{l}\text { Half spotted grouper } \\
\text { Cephalopholis hemistiktos }\end{array}$ & $11.79 \pm 1.73^{\mathrm{de}}$ & $129.87 \pm 21.12^{\mathrm{cd}}$ & $83.54 \pm 10.13^{b}$ & $34.92 \pm 4.27^{\mathrm{b}}$ & $26.37 \pm 3.35^{b}$ \\
\hline $\begin{array}{l}\text { FAO concentration } \\
\text { range in fish muscles } \\
\left(\text { FAO/WHO, 2001 }{ }^{\mathrm{a}}\right)[18]\end{array}$ & $10-56$ & $190-8810$ & $190-5020$ & $300-1340$ & $45-4520$ \\
\hline$F$ value & 11.99 & 46.94 & 1.27 & 1.12 & 1.11 \\
\hline
\end{tabular}

Mean values \pm standard error $(n=3)$. Means of samples having the same letter(s) within a column are not significantly different $(P<0.05)$.

the proximate and elemental compositions of four species of fish collected from Osinmo Reservoir, Nigeria, was carried out. All studied fish species are rich in crude protein, lipid, moisture and ash and meet the requirements for human nutritional needs. Differences in the concentration of examined minerals of fish species muscles could be due to their concentration in the water, fish physiological state and/or the ability of the fish to absorb 
the elements from their diets and water [20].

From nutritional view, FAO/WHO (2001) [18] suggested recommended dietary allowances (RDA) of Fe, Ca, $\mathrm{K}, \mathrm{Na}$ and $\mathrm{Mg}$ for male and female ( for example 9 - 50 years old) and they ranged as 8 - $18 \mathrm{mg}, 1000$ - $1300 \mathrm{mg}$, 4.5 - $4.7 \mathrm{~g}, 1.3$ - $1.5 \mathrm{~g}$ and 240 - $420 \mathrm{mg}$ per day, respectively. Consequently, consuming about $250 \mathrm{~g}$ of Indian oil sardine will cover $100 \%$ of Fe RDA and eating $500 \mathrm{~g}$ of the same fish will cover about $30 \%$ of Ca RDA. While, $500 \mathrm{~g}$ of gilt head bream sample which has the highest content of $\mathrm{K}, \mathrm{Na}$ and $\mathrm{Mg}$ will cover about $11.7 \%$, $1.5 \%$ and $4.1 \%$ of these minerals RDA, respectively.

The high chance of bioaccumulation of heavy metals in fish species (gills, viscera and muscles) leads many researchers to examine economic fish for its content of such heavy metals in parallel with its nutritive value. Table 3 showed heavy metals ( $\mathrm{Pb}, \mathrm{Mn}, \mathrm{Cu}$ and $\mathrm{Cd}$ ) content of studied fish flesh samples.

It is well known that heavy metals caused an inhibition of nerve muscle responses [21]. Lead affects the nervous system and may lead to impaired learning ability [22]. Lead can cause fetal injury and have an adverse effect on fertility. Children are extra sensitive to lead because they absorb more lead than adults. Lead also affects enzyme activity in the blood and the transport of oxygen around our bodies. It also accumulates in our bones [23]. Tabulated results showed that most of fish species had lead content less than the maximum permissible limit (2.00 ppm) as recommended by SASO (1997) [6]. Where this content ranged from 0.30 to $1.97 \mathrm{ppm}$ in gilt head bream and dusky grouper, respectively. Meanwhile, spangled emperor and half spotted grouper samples exceeded the lead permissible limit recorded 2.22 and 2.64 ppm, respectively. Moreover, there were significant differences between all studied fish in their content of lead with $F$ value of 5.50. Figure 2(a) showed $\mathrm{Pb}$ content of all replicates of studied fish and it could be easily seen that seven samples exceeded the maximum level of Lead represented $21.21 \%$ of all studied fish. Lead content of all studied fish flesh samples was in accordance with European Commission (1997) [7].

Table 3. Heavy metals content (ppm), dry weight, of studied fish flesh samples.

\begin{tabular}{|c|c|c|c|c|c|}
\hline Fish Species $\quad$ Heavy Metals & $\mathbf{P b}$ & Mn & $\mathbf{C u}$ & Cd & MPI* \\
\hline $\begin{array}{l}\text { Grey mullet } \\
\text { Liza ramada }\end{array}$ & $1.40 \pm 0.61^{\mathrm{bcd}}$ & $0.96 \pm 0.14^{\text {cd }}$ & $3.52 \pm 1.13^{\mathrm{a}}$ & $0.16 \pm 0.02^{\mathrm{cd}}$ & 0.93 \\
\hline $\begin{array}{l}\text { Sabaki tilapia } \\
\text { Oreochromis spilurus }\end{array}$ & $0.31 \pm 0.06^{\mathrm{e}}$ & $0.36 \pm 0.18^{\mathrm{d}}$ & $3.25 \pm 0.60^{\mathrm{a}}$ & $0.21 \pm 0.03^{\mathrm{cd}}$ & 0.53 \\
\hline $\begin{array}{l}\text { Indian oil sardine } \\
\text { Sardinella longiceps }\end{array}$ & $1.67 \pm 0.13^{\text {abcd }}$ & $2.28 \pm 0.16^{\mathrm{abc}}$ & $3.40 \pm 0.23^{\mathrm{a}}$ & $0.85 \pm 0.13^{\mathrm{a}}$ & 1.82 \\
\hline $\begin{array}{l}\text { Golden thread fin bream } \\
\text { Nemipterus japonicus }\end{array}$ & $1.80 \pm 0.22^{\mathrm{abc}}$ & $2.39 \pm 1.00^{\mathrm{ab}}$ & $3.97 \pm 2.08^{\mathrm{a}}$ & $0.48 \pm 0.09 b^{c}$ & 1.69 \\
\hline $\begin{array}{l}\text { Gilt head bream } \\
\text { Sparus aurata }\end{array}$ & $0.30 \pm 0.22^{\mathrm{e}}$ & $0.50 \pm 0.17^{\mathrm{d}}$ & $1.53 \pm 0.47^{\mathrm{a}}$ & $0.12 \pm 0.03^{\mathrm{d}}$ & 0.41 \\
\hline $\begin{array}{l}\text { Asian seabass } \\
\text { Lates calcarifer }\end{array}$ & $1.04 \pm 0.38^{\text {cde }}$ & $0.33 \pm 0.03^{\mathrm{d}}$ & $3.88 \pm 1.00^{\mathrm{a}}$ & $0.37 \pm 0.13 b^{c d}$ & 0.84 \\
\hline $\begin{array}{c}\text { Job fish } \\
\text { Apharus rutilanus }\end{array}$ & $0.69 \pm 0.21^{\mathrm{de}}$ & $1.03 \pm 0.67^{\mathrm{bcd}}$ & $3.24 \pm 1.14^{\mathrm{a}}$ & $0.26 \pm 0.03 b^{\text {cd }}$ & 0.88 \\
\hline $\begin{array}{l}\text { Spangled emperor } \\
\text { Lethrinus nebuloses }\end{array}$ & $2.22 \pm 0.31^{\mathrm{ab}}$ & $1.51 \pm 0.33^{\mathrm{abcd}}$ & $3.65 \pm 1.18^{\mathrm{a}}$ & $0.13 \pm 0.05^{d}$ & 1.12 \\
\hline $\begin{array}{c}\text { Dusky grouper } \\
\text { Epinephelus marginatus }\end{array}$ & $1.97 \pm 0.46^{\mathrm{abc}}$ & $0.75 \pm 0.09^{d}$ & $3.89 \pm 0.29^{\mathrm{a}}$ & $0.11 \pm 0.07^{\mathrm{d}}$ & 0.89 \\
\hline $\begin{array}{l}\text { Rusty parrot fish } \\
\text { Scarus ferrugineus }\end{array}$ & $0.94 \pm 0.24^{\text {cde }}$ & $2.62 \pm 0.44^{\mathrm{a}}$ & $3.49 \pm 0.68^{\mathrm{a}}$ & $0.54 \pm 0.24^{\mathrm{b}}$ & 1.47 \\
\hline $\begin{array}{l}\text { Half spotted grouper } \\
\text { Cephalopholis hemistiktos }\end{array}$ & $2.64 \pm 0.40^{\mathrm{a}}$ & $1.62 \pm 0.44^{\mathrm{abcd}}$ & $3.71 \pm 0.67^{\mathrm{a}}$ & $0.16 \pm 0.02^{\mathrm{cd}}$ & 1.26 \\
\hline$F$ value & 5.50 & 3.74 & 0.46 & 5.41 & - \\
\hline Limited level & $2.00^{1}$ & $5.40^{2}$ & $40.00^{3}$ & $0.50^{1}$ & 3.83 \\
\hline
\end{tabular}

Mean values \pm standard error $(\mathrm{n}=3)$. Means of samples having the same letter(s) within a column are not significantly different $(P<0.05)$. SASO (1997) [6], FAO/WHO (1984) [24] and FAO/WHO (2001) [25]. "Metal Pollution Index. 


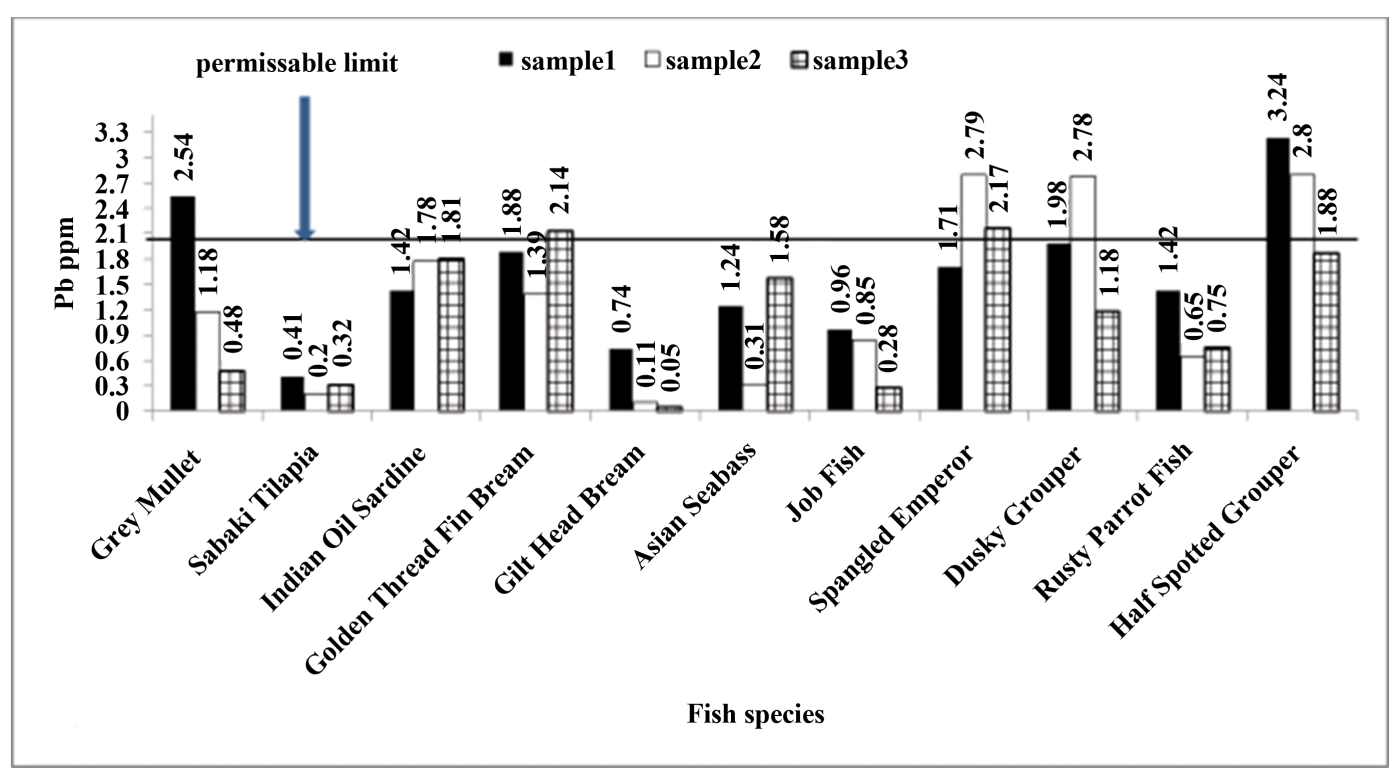

(a)

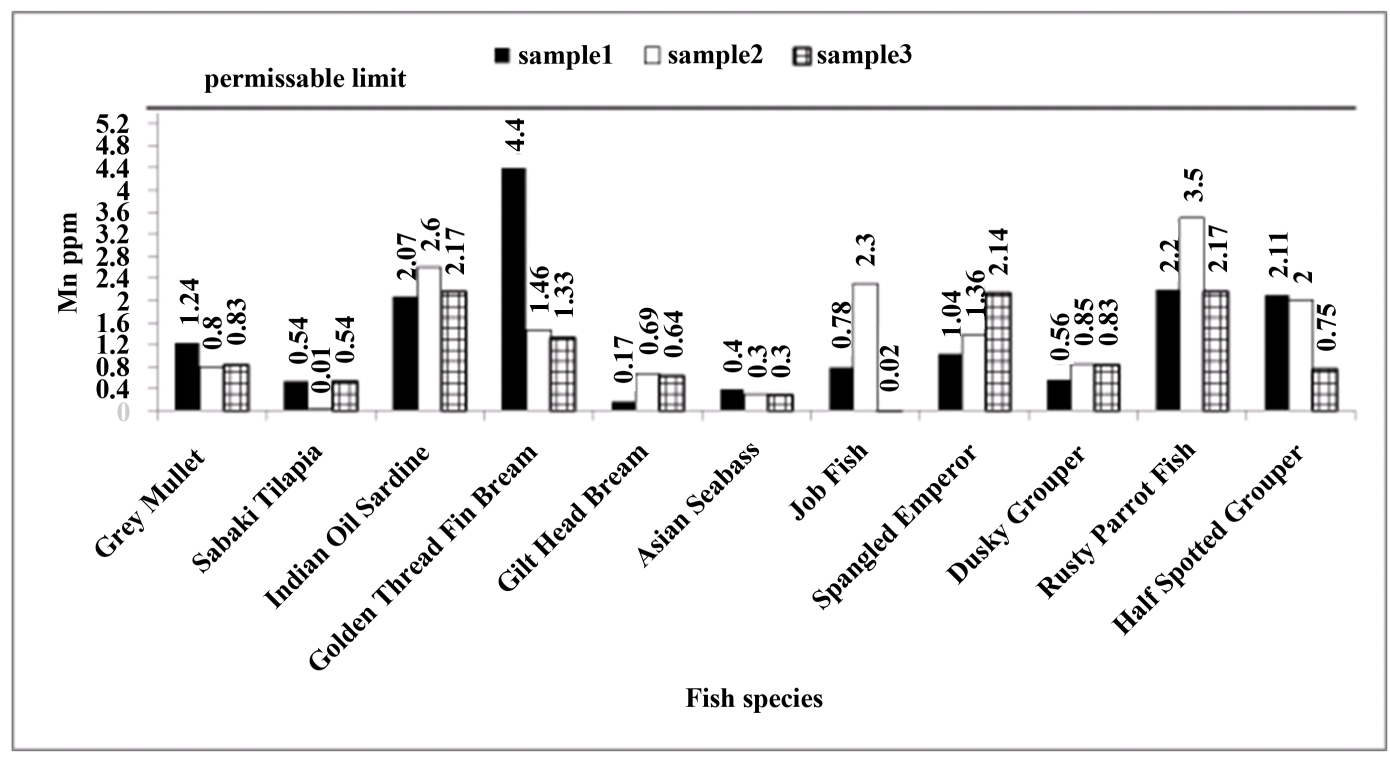

(b)

Figure 2. $\mathrm{Pb}(\mathrm{a})$ and $\mathrm{Mn}$ (b) content (ppm) of all studied fish flesh samples.

Although manganese $(\mathrm{Mn})$ is micronutrients in human nutrition as co-enzyme, it is considered as a heavy metal because its density equal 7.0 - 9.99. All studied fish samples did not exceed the permissible limits of 5.4 ppm stated by FAO/WHO (1984) [24]. Rusty parrot fish sample came first order in Mn content, where it contained $2.62 \mathrm{ppm}$ followed by golden thread fin bream $(2.39 \mathrm{ppm})$. Whilst, Asian seabass sample had the least Mn content represented $0.33 \mathrm{ppm}$, followed by sabaki tilapia sample $(0.36 \mathrm{ppm})$. There were significant differences at $P<0.05$ between all studied Mn content samples, with $\mathrm{F}$ value of 3.74. Mn content (ppm) of all studied fish flesh samples was illustrated in Figure 2(b). Illustrated results ensured that there were no sample exceeded Mn permissible limit.

As for copper $(\mathrm{Cu})$, tabulated results showed that $\mathrm{Cu}$ content of studied samples varied from $1.53 \mathrm{ppm}$ in gilt head bream to $3.97 \mathrm{ppm}$ in golden thread fin bream. Accordingly, $\mathrm{Cu}$ content of all fish samples did not exceed the maximum level $(40 \mathrm{ppm})$. There were no significant differences between all studied fish samples with $F$ value of 0.46 . Figure 3(a) showed $\mathrm{Cu}$ content (ppm) of all studied fish flesh samples. 


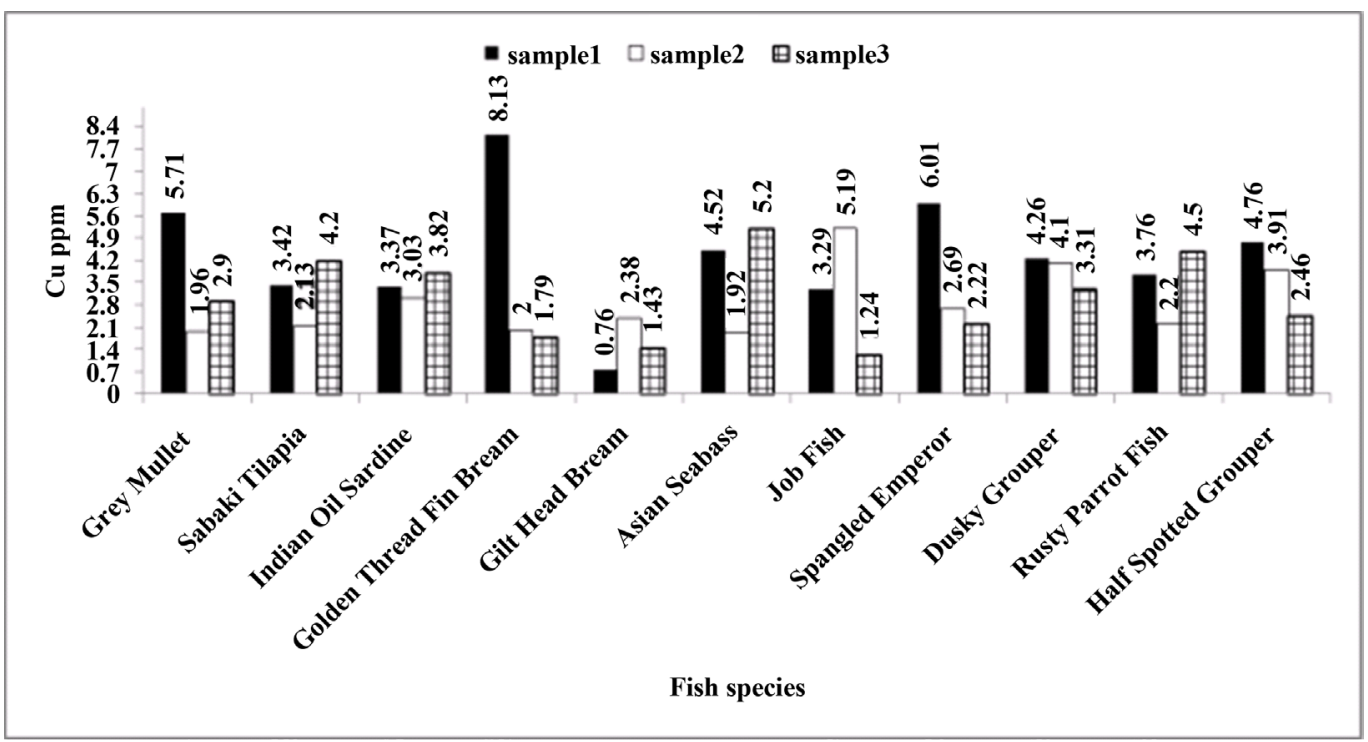

(a)

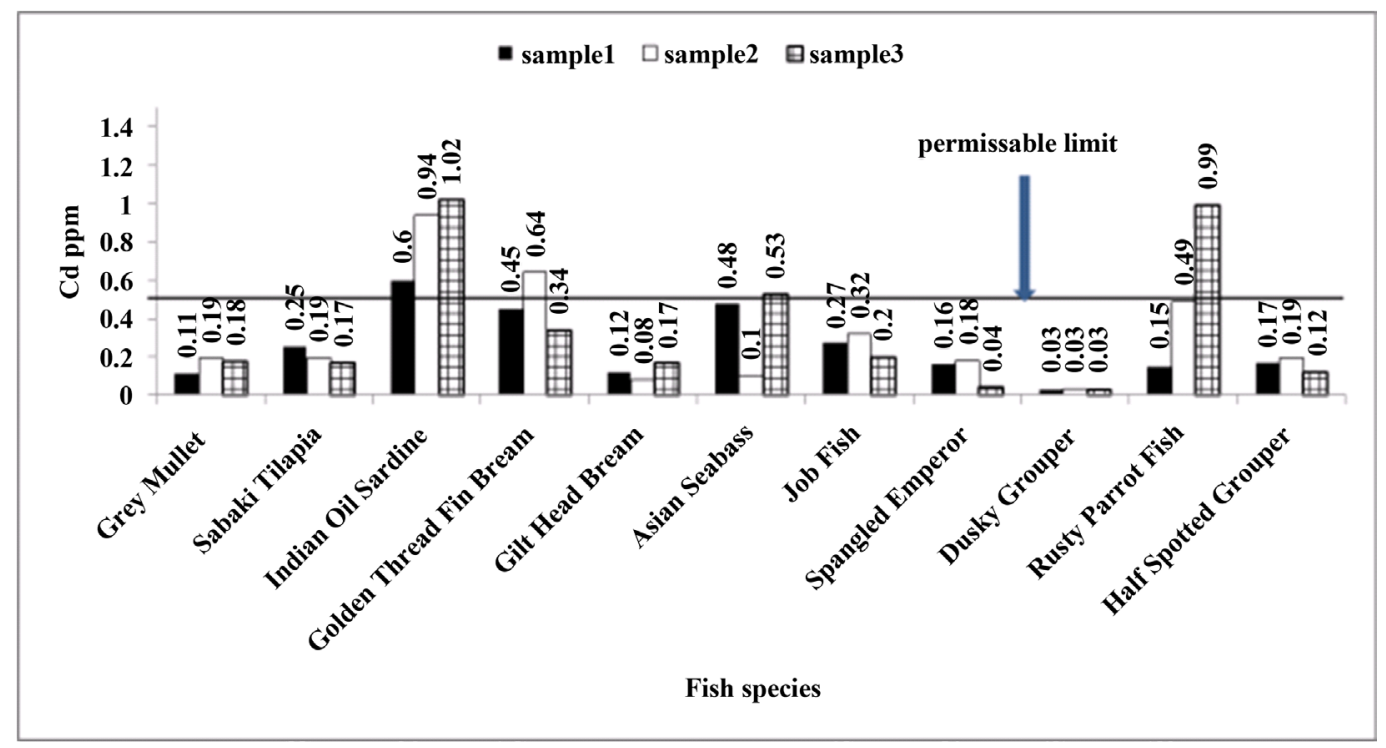

(b)

Figure 3. Cu (a) and Cd (b) content (ppm) of all studied fish flesh samples.

Cadmium has a long half-life in humans and can be carcinogenic [22]. It can be accumulated in the kidneys and caused kidney failure. Cadmium can also have an adverse effect on fertility [23]. Table 3 showed mean of $\mathrm{Cd}$ content $(\mathrm{ppm}) \pm$ standard error of studied fish flesh samples. All studied samples did not exceed the maximum level of Cd (0.50 ppm) as stated by SASO (1997) [6]. Cd content ranged from 0.11 to $0.54 \mathrm{ppm}$ in dusky grouper and rusty parrot fish, respectively. Only, Indian oil sardine contained $0.85 \mathrm{ppm}$, that exceeded the permissible limit of $\mathrm{Cd}$. The three replicates of the same fish also exceeded $0.5 \mathrm{ppm}$. There were significant differences between all fish samples with $F$ value of 5.41. Figure 3(b) showed that six samples exceeded the maximum level of cadmium, represented $18.18 \%$ of all studied fish.

A similar study was carried out to provide information on heavy metal concentrations in the muscles of six commercial fish species available in Gaza Strip markets and to evaluate the possible risk associated with their consumption. The concentrations of cadmium $(\mathrm{Cd})$, lead $(\mathrm{Pb})$, copper $(\mathrm{Cu})$, manganese $(\mathrm{Mn})$, nickel $(\mathrm{Ni})$ and zinc (Zn) were determined in the muscles of Merluccius hubbsi, Micropogonias furnieri, Pangasius hypothalamus, Oreochromis niloticus, Sparus aurata and Mugil cephalus. The heavy metal concentrations found in muscles 


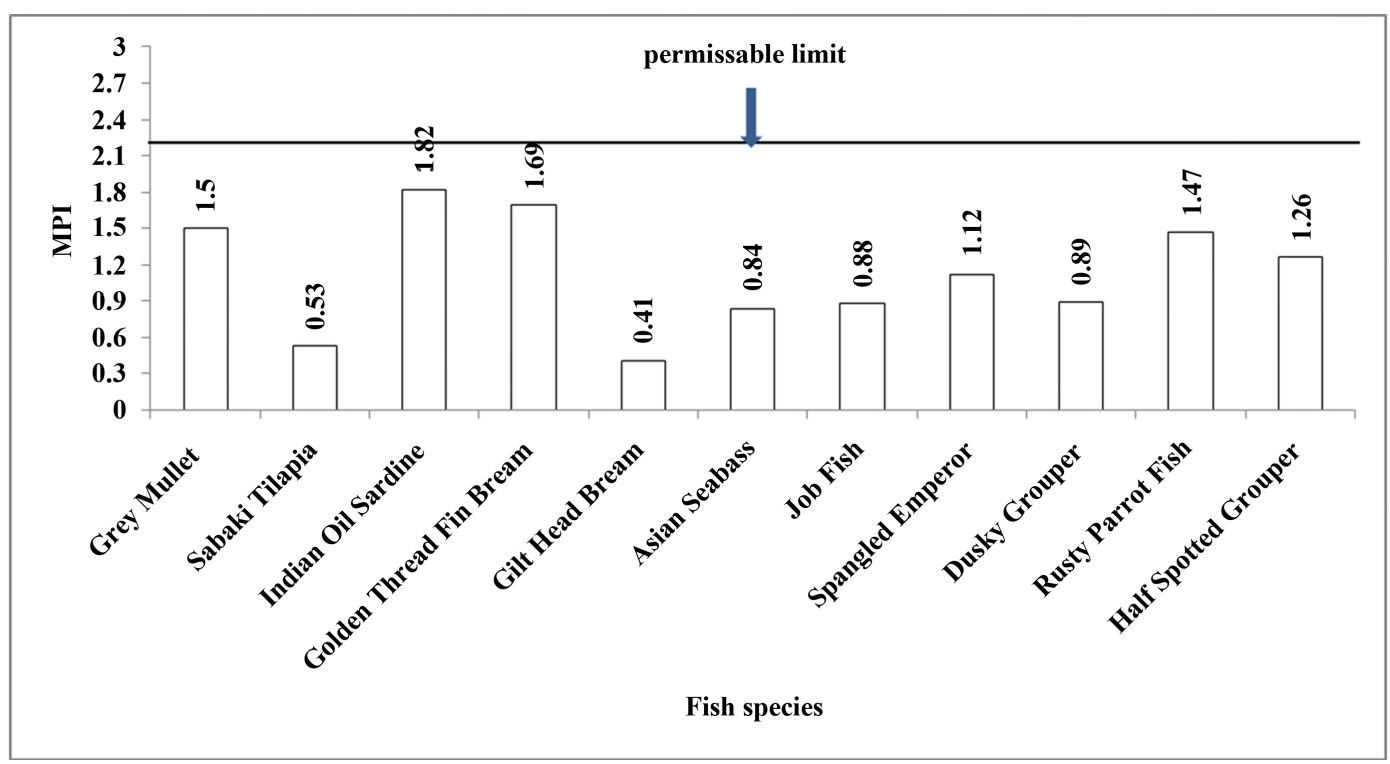

Figure 4. Metal Pollution Index (MPI) of studied fish flesh samples.

varied for Cu: 0.25 - 0.91, Zn: 3.71 - 20.54, Mn: 0.38 - 0.83, Ni: 0.45 - 0.98 and Pb: Nd-0.55 $\mu \mathrm{g} / \mathrm{g}$ wet weight. Cadmium was only detected in $M$. furnieri ( $0.09 \mu \mathrm{g} / \mathrm{g}$ wet weight). The estimated levels of all metals in this study were lower than the limits permitted by Food and Agriculture Organization of the United Nations/World Health Organization (FAO/WHO) [26].

Also, concentrations of heavy metals $(\mathrm{Cu}, \mathrm{Zn}, \mathrm{Pb}, \mathrm{Cd}, \mathrm{Fe}$ and $\mathrm{Mn}$ ) measured in muscles of fourteen benthic and pelagic fish species collected from three main landing areas (Shalateen, Hurghada and Suez) of the Egyptian Red Sea during 2014 significantly varied among fish species and were accepted by the international legislation limits as safe for human consumption [27].

Finally, the overall heavy metal (Metal Pollution Index, MPI) contents of all fish species, investigated in this study, were tabulated and illustrated (Table 3, Figure 4). It could be noticed that MPI ranged from 0.41 in gilt head bream and 1.82 in Indian oil sardine. All MPI values were below the same index calculated using the maximum levels of $\mathrm{Pb}, \mathrm{Mn}, \mathrm{Cu}$ and $\mathrm{Cd}$ (3.83). Results of this study concluded that the concentration of heavy metals in the studied fish muscles were accepted by the international legislation limits and are safe for human consumption.

Resulted findings, confirmed that Indian oil sardine could be considered a good source of iron and calcium, while gilt head bream could be used as a moderate source of potassium, sodium and magnesium. Fourteen samples from thirty three studied ones exceeded the permissible limit of $\mathrm{Pb}$ and $\mathrm{Cd}$, representing about $40 \%$. Therefore, it is strongly recommended not to eat head, gills or viscera of all fish.

\section{Acknowledgements}

The authors would like to thank Institute of Scientific Research and Revival of Islamic Heritage at Umm AlQura University (Project ID 43405028) for the financial support.

\section{References}

[1] WHO/FAO (1989) Evaluation of Food Contaminants. 33rd Report of the Joint FAO/WHO Expert Committee on Food Additives, Technical Report Series 776, Geneva.

[2] EI-Faer, M.Z., Rawdah, T.N., Attar, K.M. and Arab, M. (1992) Mineral and Proximate Composition of Some Commercially Important Fish of the Arabian Gulf. Food Chemistry, 45, 95-98. http://www.sciencedirect.com/science/article/pii/030881469290016U

[3] El-Ghasham, A., Mehanna, E.E. and Abdel-Reheem, M. (2008) Evaluation of Lead and Cadmium Levels in Fresh Water Fish Farms at Qassim Region, KSA. Journal of Agricultural and Veterinary Sciences, 1, 59-77. http://publications.qu.edu.sa/journals/1/articles/37/submission/copyedit/37-72-1-CE.pdf 
[4] Tawfik, M.S. (2009) Proximate Composition and Fatty Acids Profiles in Most Common Available Fish Species in Saudi Market. Asian Journal of clinical Nutrition, 1, 50-57. http://docsdrive.com/pdfs/ansinet/ajcn/2009/50-57.pdf http://dx.doi.org/10.3923/ajcn.2009.50.57

[5] Alturiqi, A.S. and Albedair, L.A. (2012). Evaluation of Some Heavy Metals in Certain Fish, Meat and Meat Products in Saudi Arabian Markets. Egyptian Journal of Aquatic Research, 38, 45-49. http://www.sciencedirect.com/science/article/pii/S1687428512000040

[6] SASO (Saudi Standards Metrology and Quality Organization) (1997) Maximum Limits of Contaminating Metallic Elements in Foods, Riyadh, Saudi Arabia.

http://www.inmetro.gov.br/barreirastecnicas/pontofocal/..\%5Cpontofocal\%5Ctextos\%5Cregulamentos\%5CSAU 240.p $\underline{\mathrm{df}}$

[7] Commission of the European Committee (1997) Draft Commission Regulation Setting Limits for Certain Contaminants in Food Stuffs. DocIII/5125/95/REV.3.

[8] WHO (1993) Revision of WHO Guidelines for Water Quality. WHO, Geneva.

[9] AOAC (2005) Association of Official Analytical Chemist, Official Methods of Analysis. $18^{\text {th }}$ Edition, AOAC International, Suite 500, 481 North Frederick Avenue, Gaithersburg, Maryland 20877-2417, USA.

[10] AACC (1983) American Association of Cereals Chemists. Approved Methods of the AACC, The Association. St. Paul, Mc.

[11] UNEP/FAO/IAEA/IOC (1984) Sampling of Selected Marine Organisms and Sample Preparation for Trace Metal Analysis: Reference Method for Marine Pollution Studies No. 7, Rev. 2: 19 p.

[12] Usero, J., Gonzales-Regalado, E. and Gracia, I. (1997) Trace Metals in Bivalve Molluscs Ruditapes decussatus and Ruditapes philippinarum from the Atlantic Coast of Southern Spain. Environment International, 23, 291-298. http://dx.doi.org/10.1016/S0160-4120(97)00030-5

[13] SPSS (2008) Statistical Package for Social Sciences Program. Version 17 for Windows, SPSS Inc., Chicago.

[14] Zuraini, A., Somchit, M.N., Solihah, M.H., Goh, Y.M., Arifah, A.K., Zakaria, M.S., Somchit, N., Rajion, M.A., Zakaria, Z.A. and Mat Jais, A.M. (2006) Fatty Acid and Amino Acid Composition of Three Local Malaysian Channa spp. Fish. Food Chemistry, 97, 674-678.

[15] Di Lena, G., Nevigato, T., Rampacci, M., Casini, I., Caproni, R. and Orban, E. (2016) Proximate Composition and Lipid Profile of Red Mullet (Mullus barbatus) from Two Sites of the Tyrrhenian and Adriatic Seas (Italy): A Seasonal Differentiation. Journal of Food Composition and Analysis, 45, 121-129. http://dx.doi.org/10.1016/j.jfca.2015.10.003

[16] Gupta, C.P. (2014) Role of Iron (Fe) in Body. IOSR Journal of Applied Chemistry (IOSR-JAC), 7, 38-46. http://dx.doi.org/10.9790/5736-071123846

[17] Soetan, K.O., Olaiya, C.O. and Oyewole, O.E. (2010) The Importance of Mineral Elements for Humans, Domestic Animals and Plants: A Review. African Journal of Food Science, 4, 200-222.

[18] FAO/WHO (2001) Human Vitamin and Mineral Requirements, Report of a Joint FAO/WHO Expert Consultation, Bangkok, Thailand. Food and Nutrition Division, FAO, Rome.

[19] Mogobe, O., Mosepele, K. and Masamba, W.R.L. (2015) Essential Mineral Content of Common Fish Species in Chanoga, Okavango Delta, Botswana. African Journal of Food Science, 9, 480-486. http://www.academicjournals.org/journal/AJFS/how-to-cite-article/76B4D0C55453 http://dx.doi.org/10.5897/AJFS2015.1307

[20] Adewumi, A.A., Adewole, H.A. and Olaleye, V.F. (2014) Proximate and Elemental Composition of the Fillets of Some Fish Species in Osinmo Reservoir, Nigeria. Agriculture and Biology Journal of North America, 5, 109-117. http://www.scihub.org/ABJNA/PDF/2014/3/ABJNA-5-3-109-117.pdf

[21] Mutwally, H.M.A. (1990) The Structure, Innervation and Function of Locust (Locustamigratoria) Foregut Visceral Muscle. Ph.D. Thesis, Lancaster University, Lancaster.

[22] Jaishankar, M., Tseten, T., Anbalagan, N., Mathew, B.B. and Beeregowda, K.N. (2014) Toxicity, Mechanism and Health Effects of Some Heavy Metals. Interdisciplinary Toxicology, 7, 60-72. http://dx.doi.org/10.2478/intox-2014-0009

[23] NIFES (2016) The National Institute of Nutrition and Seafood Research. Undesirable Substances in Seafood. http://nifes.no/en/research-topics/seafood-safety/undesirable-substances-seafood/

[24] FAO/WHO (1984) List of Maximum Levels Recommended for Contaminants by the Joint FAO/WHO Codex Alimentarius Commission. 2nd Edition, FAO/WHO, Rome, 1-8.

[25] FAO/WHO (2001) Food Additive and Contaminants by the Joint FAO/WHO Food Codex Alimentarius. Commission Standard Program, ALINORM 01/12A, 1-289.

[26] Elnabris, K.J., Muzyed, S.K. and El-Ashgar, N.M. (2013) Heavy Metal Concentrations in Some Commercially Impor- 
tant Fishes and Their Contribution to Heavy Metals Exposure in Palestinian People of Gaza Strip (Palestine). Journal of the Association of Arab Universities for Basic and Applied Sciences, 13, 44-51. http://dx.doi.org/10.1016/j.jaubas.2012.06.001

[27] El-Moselhy, K.M., Othman, A.I., Abd El-Azem, H. and El-Metwally, M.E.A. (2014) Bioaccumulation of Heavy Metals in Some Tissues of Fish in the Red Sea, Egypt. Egyptian Journal of Basic and Applied Sciences, 1, 97-105. http://dx.doi.org/10.1016/j.ejbas.2014.06.001 